\title{
Ethnobotanical appraisal and medicinal use of plants in Patriata, New Murree, evidence from Pakistan
}

Ejaz Ahmed ${ }^{1 *}$, Muhammad Arshad', Abdul Saboor ${ }^{2}$, Rahmatullah Qureshi', Ghazala Mustafa', Shumaila Sadiq ${ }^{2}$ and Sunbal Khalil Chaudhari ${ }^{1}$

\begin{abstract}
Background: This paper reflects the empirical findings of an ethnobotanical survey which was undertaken in Patriata (New Murree) of district Rawalpindi in Pakistan. The aims and objectives of the study were to document indigenous knowledge of plants particularly of medicinal, veterinary, fruit, vegetable, fodder, fuel etc.
\end{abstract}

Methods: For this purpose, the whole area was surveyed for documenting folk knowledge using a semi-structured questionnaire. A total of 93 plants species belonging to 80 genera and 56 families were found in a variety of uses by the local people for the accomplishment of their basic needs. The study further employs binary logit regression model of medicinal uses of these plants so as to identify the probability of occurrence of medicinal use of woody or non-woody plants keeping other plant characteristics in view.

Results: Ethnobotanical data shows that most plants are used for medicinal and fodder purposes (27.93\% each), followed by fuel (16.90\%), fruit (6.55\%), vegetable (5.52\%) and ethno-veterinary (3.79\%). There is also an established association of medicinal use of plants to the fruits use. Non-woody plants have high tendency towards medicinal use of the plants as compared to woody plants. Annual plants are less likely to be directly associated with medicinal use of plants in the surveyed vegetation. Underground plant parts are more likely to be used for medicinal purposes as revealed from the Logit expressions.

Conclusions: The study revealed that most of the plants are used for medicinal and fodder purposes. The results of Logit Model showed that the probabilities of plant species for their medicinal use are associated to the woody or non-woody, aerial or underground, perennial or annual characteristics of plants. One should be careful in completely generalizing the results as the survey findings are sensitive to the plant species and the vegetation under consideration. But it can be specified that there exists either some positive or negative association of medicinal use of plants to the various characteristics of plant species.

Keywords: Ethnobotany, Medicinal use of plants, Probabilities, Logit expression, Patriata, Murree, Pakistan

\section{Background}

Ethnobotany accounts for the study of relationship between people and plants for their use as medicines, food, shelter, clothing, fuel, fodder and other household purposes [1]. It deals with the interaction of indigenous plants and the local inhabitants of the area. The aim of ethnobotanists is to explore how these plants are used as

\footnotetext{
* Correspondence: ejazabbasi2001@yahoo.com

${ }^{1}$ Department of Botany, PMAS-Arid Agriculture University Rawalpindi,

Rawalpindi, Pakistan

Full list of author information is available at the end of the article
}

food, clothing, shelter, fodder, fuel, furniture and how medicinal use of such plants is associated to other characteristics of the plant species. It is a multidisciplinary science that studies "the relationship between a given society and its environment and in particular the plant world". They understand and collect the knowledge of valuable plants by the use of anthropological methods [2].

Humans are mainly dependant on plants for medicine and therapeutics and still 70 percent of the world population depends on medicinal plants for their primary healthcare needs [3]. Preservation and enhancement of

\section{Biomed Central}


indigenous plant knowledge is actually rescuing a global heritage [4]. Ethnobotanical studies in various areas of Pakistan have been carried out [5-9].

Since the advancement in the field of ethnobotany, importance of traditional ethnobotanical knowledge in the traditions and culture of rural populations have fully been realized and documented in most parts of the world. But in developing countries where populations are more dependants upon traditional ethnobotanical knowledge, the understanding of this fact needs to be matured.

The present study was aimed to explore the traditional utilization of plants of Patriata, New Murree located in district Rawalpindi. The study area is part of country's richest biodiversity centre and a source of ethnobotanical knowledge. Most of the population of the area is rural with low literacy rate and they also lack modern health facilities, hence they are more dependant upon natural resources especially plants for their healthcare and to compensate their low income as well. Topographically the area mainly comprises hills and slopes and therefore very little accessed for research studies. The present study would prove very fruitful in depicting the traditional affiliation and dependence of rural people with plant resources of the area. The study further explored the probabilistic association of medicinal use of such plants with other peculiar characteristics of plants including some other domestic uses.

\section{Method}

\section{Research area, climate and vegetation}

Patriata is a famous hill station located at about $65 \mathrm{Km}$ North East of Islamabad. It is located at $33^{\circ} 51^{\prime} \mathrm{N}$ latitude and $73^{\circ} 28^{\prime} \mathrm{E}$ longitudes and it is present at an altitude of 2100-2743 Meters above sea level. Patriata is the highest place in the area and the hill top stands 2743 Meters above from sea level. Most of the area comprises mountain slopes with soil derived from weathering of bedrock resulting in mixed residuum and colluvium. Due to its location at high altitude, the climate usually remains pleasant from April to September, while it becomes extreme cold type during October to March. Snowfall usually happens from mid December to February and the temperature may drop up to $-10^{\circ} \mathrm{C}[10]$.

The area falls under Sub-tropical and Moist temperate forests in which Chir Pine (Pinus roxburghii) and blue pine (P. wallichiana) are the most dominant tree species in the area. Due to cool and humid conditions for most of the year, the vegetation in the area comprises a wide variety of trees, herbs, shrubs and climbers. Ground cover comprises a wide variety of angiosperms along with ferns and mosses.

\section{Field work and collection of data}

The ethnobotanical knowledge was documented through a semi-structured questionnaire. During field visits, interviews were conducted from 37 local people especially older people and rural herbalists (Hakeems) who were familiar with traditional uses of plants particularly for medicinal, veterinary, fruit, vegetable, fodder, fuel and others. The queries were repeatedly made to increase the reliability of the data. Identification of plant samples was done by using the available literature [11-14]. Plant specimens were collected, pressed, dried and identified in the Herbarium of, Quaid-i-Azam University Islamabad. After proper identification, these plant specimens were deposited in the Herbarium, Pir Mehr Ali Shah Arid Agriculture University Rawalpindi as voucher specimen for future references.

\section{Logit model}

Logit expression is helpful in understanding the in-depth probabilistic relationships among various variables. In the present case, medicinal use is attributed to various characteristics and traits of the plants. By analyzing data through logit model we become able to empirically estimate the probability of medicinal use of plants due to woody and non-woody, aerial and underground, perennial and annual nature of plants in addition to the use of plant as fodder or as fruit.

There is wide use of Logit Model in Plant and Animal sciences particularly to verify the probability of occurrence of an event (for instance, the probability of use of woody or non-woody plants in medicinal use). By using this model we become confident to relate the characteristics of plant species in a particular ecosystem. This is the inherent beauty of the model that it takes into account the exogenous variables like overall vegetation in a particular ecosystem. In order to incorporate taxonomies of different plant species in the same model, a huge set of data and associated information is required which is beyond the scope of this study. At least, we authenticate our findings by employing Logit specifications which otherwise remain a perception and indigenous observation. The advantage of Logit results are that the findings can be applied and specified for having a broad picture in other ecosystems as well. Moreover, the typical probabilistic relationships further help in pursuing research on important variables across regions of the similar flora.

The study employs binary logit regression model of medicinal use of 93 plants species of Patriata region because we consider the case where response Medicinal Use (MU) is binary that will take the value of 1 if yes is associated with the plant; zero (0) is taken if there is no medicinal use of plant. The logit model for medicinal use of plant thus took the form

$$
\operatorname{Logit}\left(L_{i}\right)=\beta_{0}+\sum_{j=1}^{k} \beta_{i} X_{i j}+\mu_{i}
$$


Table 1 Ethnobotanical uses of plants of Patriata, New Murree

\begin{tabular}{|c|c|c|c|c|}
\hline S. no & $\begin{array}{l}\text { Plants names/ } \\
\text { voucher number }\end{array}$ & Local name & Family & Ethnobotanical uses \\
\hline 01 & $\begin{array}{l}\text { Acacia catechu } \\
\text { (L.f.) Willd/ej-03 }\end{array}$ & Kikar & Mimosaceae & $\begin{array}{l}\text { Bark along with leaves of Olea ferruginea were used for tea making by the } \\
\text { people in early days used for treating skin diseases and as cooling agent. } \\
\text { Wood is used in roof thatching, fuel wood, coal formation and fencing. }\end{array}$ \\
\hline 02 & $\begin{array}{l}\text { Acacia modesta } \\
\text { L./ej-04 }\end{array}$ & Phulai & Mimosaceae & $\begin{array}{l}\text { Branches are used as tooth stick (Miswak) for teeth cleansing and tooth } \\
\text { decay. The gum is used as tonic and given in general weakness. Wood is } \\
\text { used for agricultural implements e.g. Hull, fuel, branches used for fencing } \\
\text { fields and leaves are browsed by goats. }\end{array}$ \\
\hline 03 & $\begin{array}{l}\text { Achyranthis } \\
\text { aspera L./ej-06 }\end{array}$ & Puth Kanda, Chooroon & Amaranthaceae & $\begin{array}{l}\text { Roots and leaves are boiled in water to make decoction, which is given in } \\
\text { toothache and digestive problems. Leaf paste is applied externally on } \\
\text { insect bite. The powder of roots is used in bloody diarrhoea. }\end{array}$ \\
\hline 04 & $\begin{array}{l}\text { Adiantum } \\
\text { capilus-veneris } \\
\text { L./ej-07 }\end{array}$ & Hansraal & Adiantaceae & Decoction of leaves is prescribed in cold, cough, flue and asthma. \\
\hline 05 & $\begin{array}{l}\text { Aesculus indica } \\
\text { (Wall ex Camb.) } \\
\text { Hook. f./ej-09 }\end{array}$ & Ban khor & Hippocastinaceae & $\begin{array}{l}\text { Oil extracted from fresh fruits is applied externally on wounds. The } \\
\text { powder of seeds is taken orally against acidity and digestive problems for } \\
\text { both humans and animals. Leaves are used as fodder and dried branches } \\
\text { are used for fuel source. }\end{array}$ \\
\hline 06 & $\begin{array}{l}\text { Ajuga bracteosa } \\
\text { Wall. Ex Benth./ } \\
\text { ej-11 }\end{array}$ & Guchi & Lamiaceae & The leaf paste is used orally against constipation. \\
\hline 07 & $\begin{array}{l}\text { Aloe vera (L.) } \\
\text { Burm f./ej-12 }\end{array}$ & Kanwar gandal & Aloaceae & $\begin{array}{l}\text { The salt is dusted on pulp and kept overnight under moonlight which is } \\
\text { given early morning to treat tumours in the digestive tract. The same is } \\
\text { given as an appetizer and tonic. As an appetizer and treatment of leprosy, } \\
\text { the same is given to cattle. }\end{array}$ \\
\hline 08 & $\begin{array}{l}\text { Alternanthera } \\
\text { pungens Kunth./ } \\
\text { ej-13 }\end{array}$ & Lundri & Amaranthaceae & The powder of plant is used in jaundice. Whole plant is used for fodder. \\
\hline 09 & $\begin{array}{l}\text { Amaranthis } \\
\text { viridis L./ej-14 }\end{array}$ & Ganiar & Amaranthaceae & $\begin{array}{l}\text { Fresh green leaves are used as potherb and given to treat constipation. } \\
\text { Aerial parts are used as fodder and leaves are given to young animals to } \\
\text { induce puberty. }\end{array}$ \\
\hline 10 & $\begin{array}{l}\text { Artimesia } \\
\text { scoparia Waldst } \\
\text { \& Kit./ej-22 }\end{array}$ & Chahoo & Asteraceae & $\begin{array}{l}\text { Juice of fresh leaves mixed with brown sugar and given orally in malarial } \\
\text { fever, skin disease like scabies, pimples and supposed to possess cooling } \\
\text { effects. The plant is used as fodder. }\end{array}$ \\
\hline 11 & $\begin{array}{l}\text { Asparagus } \\
\text { adscendense } \\
\text { Roxb./ej-24 }\end{array}$ & Sumbloo, Sufaid Musli & Asparagaceae & $\begin{array}{l}\text { The extract of tuberous roots is used in diarrhoea and dysentery. Tubers } \\
\text { are also used for animal problems. Leaves are browsed by goats. }\end{array}$ \\
\hline 12 & $\begin{array}{l}\text { Bauhinia } \\
\text { variegata L./ej-30 }\end{array}$ & Kachnar, Kuliarh & Caesalpinaceae & $\begin{array}{l}\text { Buds locally called "Kalian" are used as vegetable given in digestive } \\
\text { problems. The leaves are used as fodder and branches as fuel. }\end{array}$ \\
\hline 13 & $\begin{array}{l}\text { Berberis lycium } \\
\text { Royle./ej-31 }\end{array}$ & Sumbal & Berberidaceae & $\begin{array}{l}\text { The paste of root bark is externally applied on wounds. Powdered bark is } \\
\text { mixed in water and the paste is applied on bone fracture. Crushed bark is } \\
\text { soaked in water and the resultant extract is taken early morning to treat } \\
\text { diabetes, scabies, boils and pimples. The extract possesses cooling effect } \\
\text { and seldom used in winter season. Fruits are edible. Leaves are used as } \\
\text { fodder and dried branches for fuel. }\end{array}$ \\
\hline 14 & $\begin{array}{l}\text { Bergenia ciliata } \\
\text { (Haw.) Sternb./ } \\
\text { ej-32 }\end{array}$ & Bhat-Phay & Saxifragaceae & $\begin{array}{l}\text { The powder of roots is given along with Deesi ghee in diabetes and skin } \\
\text { diseases. The same is believed in reducing blood cholesterol. }\end{array}$ \\
\hline 15 & $\begin{array}{l}\text { Bergenia } \\
\text { stracheyi (Hook f. } \\
\text { \& Thoms.) } \\
\text { Engle./ej-33 }\end{array}$ & Bhat-Phay & Saxifragaceae & $\begin{array}{l}\text { The powder of roots is dusted on wounds. The powder of roots is given } \\
\text { with milk orally early morning for digestive ulcers. Aerial parts of the plant } \\
\text { are grazed by animals. }\end{array}$ \\
\hline 16 & $\begin{array}{l}\text { Bombax ceiba L./ } \\
\text { ej-36 }\end{array}$ & Sanbal & Bombacaceae & $\begin{array}{l}\text { Large pieces of bark are removed and tied over the wounds to heal. The } \\
\text { wood is used for fuel source. Cottony fibres attached with seeds used in } \\
\text { stuffing pillows. }\end{array}$ \\
\hline 17 & $\begin{array}{l}\text { Broussonetia } \\
\text { papyrifera (L.) } \\
\text { L'Herit ex Vent./ } \\
\text { ej-37 }\end{array}$ & Jangli Toot & Moraceae & $\begin{array}{l}\text { This plant is planted in sliding areas because of its rapid vegetative } \\
\text { propagation. Leaves are used as fodder and other parts for fuel wood. }\end{array}$ \\
\hline
\end{tabular}




\section{Table 1 Ethnobotanical uses of plants of Patriata, New Murree (Continued)}

\begin{tabular}{|c|c|c|c|c|}
\hline 18 & $\begin{array}{l}\text { Calotropis } \\
\text { procera (Willd.) } \\
\text { R. Br./ej-39 }\end{array}$ & Aak & Asclepiadaceae & $\begin{array}{l}\text { The leaves are warmed and tied over the wounds and used as poultice } \\
\text { for their quick healing. The latex from stem and leaves is applied upon } \\
\text { teeth to get rid of the worms. Extreme care must be taken because latex } \\
\text { is extremely poisonous. Latex is applied externally on skin diseases. }\end{array}$ \\
\hline 19 & $\begin{array}{l}\text { Carrisa opaca } \\
\text { Stapf. Ex. } \\
\text { Haines/ej-42 }\end{array}$ & Garanda & Apocynaceae & $\begin{array}{l}\text { Decoction of fresh leaves is used against hepatitis and jaundice. Fruits are } \\
\text { edible and used as digestive stimulant. Fruits are edible and also sold by } \\
\text { poor people for generating their income. Dried branches are used for fuel } \\
\text { and the leaves are browsed by goats. }\end{array}$ \\
\hline 20 & $\begin{array}{l}\text { Cassia fistula } \\
\text { L./ej-43 }\end{array}$ & Amaltas & Caesalpinaceae & $\begin{array}{l}\text { The pulp of fruits is used against constipation. Leaves are used as fodder } \\
\text { and dried branches are used for fuel. The fruits are collected by local herb } \\
\text { sellers called "Pensaries" and Hakeems and used in various herbal } \\
\text { medicines. Pulp of fruits is also used to relieve constipation in cattle. }\end{array}$ \\
\hline 21 & $\begin{array}{l}\text { Cedrus deodara } \\
\text { (Royle. ex Lamb.) } \\
\text { Loud./ej-44 }\end{array}$ & Diarr, Deodar & Pinaceae & $\begin{array}{l}\text { Small pieces of stem are boiled in water to get oily extract called "Lou" } \\
\text { which is used as aphrodisiac. The wood of plant is used for making doors, } \\
\text { windows and cupboards. It is considered very unique for interior wood- } \\
\text { work due to its characteristic smell, insect resistance and is also very } \\
\text { expensive. }\end{array}$ \\
\hline 22 & $\begin{array}{l}\text { Chinopodium } \\
\text { album L./ej-48 }\end{array}$ & Bathu, Karhan saag & Chinopodiaceae & $\begin{array}{l}\text { Fresh green leaves are used as spinach. It is used as a digestive stimulant. } \\
\text { Leaves are used as fodder. }\end{array}$ \\
\hline 23 & $\begin{array}{l}\text { Cissampelos } \\
\text { pareira L./ej-52 }\end{array}$ & Ghorhi Sumbi, Pla jarrhi & Menispermaceae & $\begin{array}{l}\text { Fresh leaves are crushed and the extract mixed with sugar is used against } \\
\text { diarrhoea and dysentery. Leaves are used as fodder. }\end{array}$ \\
\hline 24 & $\begin{array}{l}\text { Convolvulus } \\
\text { arvensis L./ej-58 }\end{array}$ & Lily & Convolvulaceae & $\begin{array}{l}\text { Leaves are used as spinach to get rid of intestinal worms. The plant is } \\
\text { having purgative effect and is also used against constipation. }\end{array}$ \\
\hline 25 & $\begin{array}{l}\text { Cotinus coggyra } \\
\text { Scop./ej-63 }\end{array}$ & Bhann, Phann. & Anacardiaceae & $\begin{array}{l}\text { The leaves are used for fodder purpose. Dried branches are used for fuel } \\
\text { wood. Its young branches are used to make baskets. It branches are } \\
\text { twisted to be used as ropes. }\end{array}$ \\
\hline 26 & $\begin{array}{l}\text { Dabregeasia } \\
\text { salicifolia (D. } \\
\text { Don) Rendle/ } \\
\text { ej-68 }\end{array}$ & Sindwaar & Urticaceae & $\begin{array}{l}\text { The fruits are grinded and are used against bloody diarrhoea. Leaves and } \\
\text { branches are used as fodder. }\end{array}$ \\
\hline 27 & $\begin{array}{l}\text { Dalbergia sissoo } \\
\text { Roxb./ej-71 }\end{array}$ & Shishum, Taali & Papilionaceae & $\begin{array}{l}\text { Its plant is excellent source of furniture wood. The wood is highly durable } \\
\text { and insect resistant. Wood is also used for fuel. }\end{array}$ \\
\hline 28 & $\begin{array}{l}\text { Diosypros lotus } \\
\text { L./ej-74 }\end{array}$ & Amlok & Ebenaceae & $\begin{array}{l}\text { The fruits are edible and are used against stomach problems and } \\
\text { dyspepsia. The leaves are used as fodder and dried branches for fuel. }\end{array}$ \\
\hline 29 & $\begin{array}{l}\text { Dodonea viscosa } \\
\text { (L.) Jacq./ej-75 }\end{array}$ & Sanatha & Sapindaceae & $\begin{array}{l}\text { The leaves are boiled in water and steam is inhaled to get relief from } \\
\text { respiratory problems like cold, cough and asthma. Dried branches are } \\
\text { used for fuel for producing heat without smoke. }\end{array}$ \\
\hline 30 & $\begin{array}{l}\text { Dryopteris } \\
\text { ramosa (C. Hope) } \\
\text { C. Chr./ej-76 }\end{array}$ & Pakha, Pakhi & Dryopteridaceae & $\begin{array}{l}\text { Collection of Young leaves is made in spring season and used as } \\
\text { vegetable. It is effective against gastric ulcer and constipation. Leaves are } \\
\text { used as fodder. }\end{array}$ \\
\hline 31 & $\begin{array}{l}\text { Duchesnia indica } \\
\text { (Andr.) Focke/ } \\
\text { ej-77 }\end{array}$ & & Rosaceae & $\begin{array}{l}\text { Fruits paste is used against bloody diarrhoea. Whole plant is also used as } \\
\text { fodder. }\end{array}$ \\
\hline 32 & $\begin{array}{l}\text { Echinopes } \\
\text { echinatus Roxb./ } \\
\text { ej-78 }\end{array}$ & Hand, Barhong & Asteraceae & $\begin{array}{l}\text { Leaves are boiled and the decoction is taken orally against swelling in the } \\
\text { body. The leaves are also used as spinach. Aerial parts are used as fodder } \\
\text { for camels. }\end{array}$ \\
\hline 33 & $\begin{array}{l}\text { Emblica } \\
\text { officinalis Gaertn. } \\
\text { Fruct./ej-79 }\end{array}$ & Amla & Euphorbiaceae & $\begin{array}{l}\text { Fruits are boiled, the pulp is dried and stored and later on used for } \\
\text { making curry called "Chitt". It is also a strong digestive stimulant and also } \\
\text { has a cooling effect. Extract of the dried fruits alone or mixed with } \\
\text { yoghurt is also used against jaundice. Leaves are browsed by goats. Dried } \\
\text { wood is used for fuel. Fruits are sold in the market. }\end{array}$ \\
\hline 34 & $\begin{array}{l}\text { Eruca sativa L./ } \\
\text { ej-82 }\end{array}$ & Tara Meera & Brassicaceae & $\begin{array}{l}\text { The leaves and young branches are used as spinach and are believed to } \\
\text { be effective against skin diseases, constipation and digestive ulcers. Whole } \\
\text { plant is used for fodder. }\end{array}$ \\
\hline 35 & $\begin{array}{l}\text { Ficus glomerata } \\
\text { Roxb./ej-87 }\end{array}$ & Phagwarh & Moraceae & $\begin{array}{l}\text { Young leaves are tasted, if not bitter are collected as "Phagwalla" and } \\
\text { cooked in "Lassi" (remains of milk after extracting butter) and is especially } \\
\text { effective in treating intestinal problems. Fruits are edible and are effective } \\
\text { against constipation. Fruits called "Phagwara" are edible. Branches are } \\
\text { used as fuel. }\end{array}$ \\
\hline
\end{tabular}




\section{Table 1 Ethnobotanical uses of plants of Patriata, New Murree (Continued)}

\begin{tabular}{|c|c|c|c|c|}
\hline 36 & $\begin{array}{l}\text { Ficus virgata } \\
\text { Reinwardt. ex } \\
\text { Blume/ej-90 }\end{array}$ & Tussi & Moraceae & $\begin{array}{l}\text { Fruits are edible and are effective against digestive problems especially } \\
\text { constipation. The young leaves called "barh kandlaan" are cooked in } \\
\text { "Lassi" and are effective against digestive problems and have cooling } \\
\text { effect. Dried branches are used for fuel wood. }\end{array}$ \\
\hline 37 & $\begin{array}{l}\text { Flacourtia indica } \\
\text { (Burm.f.) Merrill/ } \\
\text { ej-91 }\end{array}$ & Kokoh & Flacourtiaceae & $\begin{array}{l}\text { The fruits are edible and are also used against diabetes. Leaves are used } \\
\text { as fodder and dried branches are used for fuel wood. }\end{array}$ \\
\hline 38 & $\begin{array}{l}\text { Geranium } \\
\text { rotundifolium } \\
\text { L./ej-95 }\end{array}$ & Ratan-jot & Geraniaceae & $\begin{array}{l}\text { The roots are dried and grinded, sugar and milk are added in it, and it is } \\
\text { used for pain in joints and also as antispasmodic. Its roots are grinded and } \\
\text { along with brown sugar used against blockage of urine and also believed } \\
\text { to be having cooling effect. }\end{array}$ \\
\hline 39 & $\begin{array}{l}\text { Grewia optiva } \\
\text { Drum. Ex. } \\
\text { Burret./ej-98 }\end{array}$ & Tamman, Dhamman & Tiliaceae & $\begin{array}{l}\text { Leaves are given to cattle especially during delivery for quick discharge of } \\
\text { afterbirth. It is also given to young animals to induce puberty. Branches } \\
\text { are soaked in water and the detached bark is used for making ropes. } \\
\text { Leaves are used as fodder. }\end{array}$ \\
\hline 40 & $\begin{array}{l}\text { Hedera } \\
\text { nepalensis K. } \\
\text { Koch./ej-100 }\end{array}$ & Baleri, Albhambar & Araliaceae & $\begin{array}{l}\text { The dried branches and leaves are grinded and the powder is used early } \\
\text { in the morning with water against diabetes. }\end{array}$ \\
\hline 41 & $\begin{array}{l}\text { Ipomoea } \\
\text { purpurea (L.) } \\
\text { Roth./ej-106 }\end{array}$ & Aerh & Convolvulaceae & $\begin{array}{l}\text { Leaves are grinded and the extract is used for washing hairs to get rid of } \\
\text { lices. Whole plant is used as fodder. }\end{array}$ \\
\hline 42 & $\begin{array}{l}\text { Jasminum } \\
\text { officinale L./ } \\
\text { ej-108 }\end{array}$ & Chambeli & Oleaceae & $\begin{array}{l}\text { The aqueous extract of leaves is externally applied on skin having scabies } \\
\text { or any allergic problem. The plant is also planted as ornamental on } \\
\text { graves. }\end{array}$ \\
\hline 43 & $\begin{array}{l}\text { Juglans regia } \\
\text { L./ej-109 }\end{array}$ & Akhore, Akhrot & Juglandiaceae & $\begin{array}{l}\text { Seeds are edible and are also effective for cardiac patients and as tonic. } \\
\text { Pericarp of fruit, fresh leaves and bark (locally called Dandaasa) is used for } \\
\text { cleaning of teeth and mouth ulcers. Dried wood is light weight and is } \\
\text { used for making furniture. Wood is also used for fuel. }\end{array}$ \\
\hline 44 & $\begin{array}{l}\text { Justicia adhatoda } \\
\text { L./ej-110 }\end{array}$ & Baikkarh & Acanthaceae & $\begin{array}{l}\text { Leaves are grinded and dissolved in water and this extract is taken orally } \\
\text { early morning against diabetes, scabies, boils, pimples and other skin } \\
\text { diseases. It is having drying effect and deesi ghee is used during its use. } \\
\text { Dried branches are used for fuel. Green Leaves are used in producing } \\
\text { smoky fire to drive away the insects from cattle. }\end{array}$ \\
\hline 45 & $\begin{array}{l}\text { Lepidium sativum } \\
\text { L./ej-120 }\end{array}$ & Halyan & Brassicaceae & $\begin{array}{l}\text { Its seeds are put in eyes, which produce mucilage which is very effective } \\
\text { in cleaning eyes and especially used to get rid of dust from eyes. When } \\
\text { the seeds are taken out they carry these materials out. }\end{array}$ \\
\hline 46 & $\begin{array}{l}\text { Lonicera } \\
\text { quinquelocularis } \\
\text { Hardwicke/ } \\
\text { ej-121 }\end{array}$ & Phutuk & Caprifoliaceae & $\begin{array}{l}\text { Fresh leaves are crushed and the extract is poured in eyes to cure the } \\
\text { cataract and to improve vision. Fresh leaves are used as fodder for goats. }\end{array}$ \\
\hline 47 & $\begin{array}{l}\text { Mallotus } \\
\text { philipensis (Lam.) } \\
\text { Muell./ej-123 }\end{array}$ & Kamila & Euphorbiaceae & $\begin{array}{l}\text { The fruits are crushed and used orally to treat bloody diarrhoea. The } \\
\text { leaves are used as "Koochan" to wash utensils. The leaves are used as } \\
\text { fodder and branches for fuel. }\end{array}$ \\
\hline 48 & $\begin{array}{l}\text { Medicago } \\
\text { polymorpha } \\
\text { L./ej-127 }\end{array}$ & Maeserhi, Maina & Fabaceae & $\begin{array}{l}\text { Leaves and young branches are picked and used as spinach. It is also } \\
\text { effective against constipation and other digestive problems. Whole plant } \\
\text { is used for fodder. }\end{array}$ \\
\hline 49 & $\begin{array}{l}\text { Melia azedarach } \\
\text { L./ej-128 }\end{array}$ & Dharek & Meliaceae & $\begin{array}{l}\text { The leaves are grinded and the extract is used against scabies, pustules, } \\
\text { pimples, boils and other skin diseases. Leaves are used as fodder and } \\
\text { dried branches for fuel. It is also planted in lawns for shade in summer. }\end{array}$ \\
\hline 50 & $\begin{array}{l}\text { Mentha arvensis } \\
\text { L./ej-130 }\end{array}$ & Kala Poodina & Lamiaceae & $\begin{array}{l}\text { Leaves of Mentha arvensis, young fruits of Zanthoxylum alatum are } \\
\text { grinded with seeds of Punica granatum, and green chillies to make } \\
\text { "Chatni" which is carminative and have cooling effect. It is also a } \\
\text { digestive stimulant. }\end{array}$ \\
\hline 51 & $\begin{array}{l}\text { Mentha longifolia } \\
\text { (L.) Hudson/ } \\
\text { ej-131 }\end{array}$ & Sufaid Poodina & Lamiaceae & $\begin{array}{l}\text { Leaves of Mentha longifolia, young fruits of Zanthoxylum alatum are } \\
\text { grinded with seeds of Punica granatum, and green chillies to make } \\
\text { "Chatni" which is carminative and have cooling effect. It is also a digestive } \\
\text { stimulant. Dried leaves are taken orally to stop vomiting. Its leaves are } \\
\text { added in green tea and used for digestive problems and cholera. }\end{array}$ \\
\hline 52 & $\begin{array}{l}\text { Morus alba L./ } \\
\text { ej-137 }\end{array}$ & Sufaid Shehtoot & Moraceae & $\begin{array}{l}\text { The fruits are edible and are used as digestive stimulant and to relieve } \\
\text { constipation and other digestive problems. The leaves are used for fodder. } \\
\text { Wood is used for furniture and fuel. }\end{array}$ \\
\hline
\end{tabular}


Table 1 Ethnobotanical uses of plants of Patriata, New Murree (Continued)

\begin{tabular}{|c|c|c|c|c|}
\hline 53 & $\begin{array}{l}\text { Morus nigra } \\
\text { L./ej-138 }\end{array}$ & Kala Shehtoot & Moraceae & $\begin{array}{l}\text { The fruits are edible and are used as digestive stimulant and to relieve } \\
\text { constipation and other digestive problems. The leaves are used for fodder. } \\
\text { Wood is used for furniture and fuel. }\end{array}$ \\
\hline 54 & $\begin{array}{l}\text { Myrsine Africana } \\
\text { L./ej-139 }\end{array}$ & Khookhal & Myrsinaceae & $\begin{array}{l}\text { Grinded fruits are used against intestinal worms. Leaves are used as } \\
\text { fodder and branches for fuel. }\end{array}$ \\
\hline 55 & $\begin{array}{l}\text { Nerium indicum } \\
\text { Mill./ej-141 }\end{array}$ & Ganeera, Kaner & Apocynaceae & $\begin{array}{l}\text { The branches are used as Miswak (toothbrush) to get rid of worms, but its } \\
\text { liquid extract in the branches and leaves is highly poisonous so extreme } \\
\text { care should be taken not to be taken orally. The plant is used as } \\
\text { ornamental due to its beautiful flowering. }\end{array}$ \\
\hline 56 & $\begin{array}{l}\text { Olea ferruginea } \\
\text { Royle./ej-143 }\end{array}$ & Kahu & Oleaceae & $\begin{array}{l}\text { The leaves along with bark pieces of Acacia catechu were used by people } \\
\text { in early days to make tea. It was especially used against cough, cold, flue } \\
\text { and skin diseases. Young leaves are chewed to avoid toothache and } \\
\text { mouth ulcers. Young branches are used as Miswak. The wood is extremely } \\
\text { durable and is extensively used. Its elongated logs are used as guarders in } \\
\text { roof thatching. The straight branches are used as handles for labour's } \\
\text { tools. The leaves are used as fodder and dry branches are used for fuel. } \\
\text { The wood yield more heat without smoke so its wood is especially used } \\
\text { during extreme winter. The wood is also insect resistant. }\end{array}$ \\
\hline 57 & $\begin{array}{l}\text { Olea glandulifera } \\
\text { Wall. ex G. Don./ } \\
\text { ej-144 }\end{array}$ & Barh-koh & Oleaceae & The leaves are used as fodder and dry branches are used for fuel. \\
\hline 58 & $\begin{array}{l}\text { Otostegia } \\
\text { limbata (Benth.) } \\
\text { Boiss./ej-145 }\end{array}$ & Chita jand & Lamiaceae & $\begin{array}{l}\text { Leaves are boiled and the extract is taken orally against mouth ulcers and } \\
\text { skin diseases. Young leaves are also chewed against mouth ulcers. The } \\
\text { leaves are browsed by goats. }\end{array}$ \\
\hline 59 & $\begin{array}{l}\text { Oxalis } \\
\text { corniculata L./ } \\
\text { ej-146 }\end{array}$ & Khat-mith & Oxalidaceae & $\begin{array}{l}\text { The leaves of the plant are crushed and the extract is used orally against } \\
\text { jaundice. The whole plant is used for fodder. }\end{array}$ \\
\hline 60 & $\begin{array}{l}\text { Pinus roxburgii } \\
\text { Sergent/ej-151 }\end{array}$ & Chirr & Pinaceae & $\begin{array}{l}\text { Juvenile apex of the stem is grinded and is used against bloody diarrhoea. } \\
\text { Tuberculosis patients are advised to keep sitting under its shade for quick } \\
\text { recovery. The wood of the plant is used for timber and fuel purpose. The } \\
\text { resin obtained is used in soap industry. The seeds are edible. Dried leaves } \\
\text { and logs are used in roof thatching. The heartwood is highly inflammable } \\
\text { and its small pieces are used for ignition purpose at homes. }\end{array}$ \\
\hline 61 & $\begin{array}{l}\text { Pinus wallichiana } \\
\text { Jackson/ej-152 }\end{array}$ & Bainrh, Biarh & Pinaceae & $\begin{array}{l}\text { The wood of the plant is used as timber and fuel. It is also used for } \\
\text { obtaining resin. Dried leaves and logs are used in roof thatching. }\end{array}$ \\
\hline 62 & $\begin{array}{l}\text { Plantago } \\
\text { lanceolata L./ } \\
\text { ej-153 }\end{array}$ & Batti, Chamchi patra & Plantaginaceae & $\begin{array}{l}\text { The leaves are crushed and mixed with brown sugar and used as cooling } \\
\text { agent for stomach. }\end{array}$ \\
\hline 63 & $\begin{array}{l}\text { Punica granatum } \\
\text { L./ej-159 }\end{array}$ & Darruni & Punicaceae & $\begin{array}{l}\text { The seeds along with young fruits of Zanthoxylum alatum, leaves of } \\
\text { Mentha longifolia and green chillies are used to make "Chattni" which is a } \\
\text { digestive stimulant. Its seeds are highly carminative. Extract of seeds have } \\
\text { cooling effect and is especially used in summer. The rind of fruits is dried, } \\
\text { powdered and mixed with sugar is used against diarrhoea for both } \\
\text { humans and cattle. Branches are used for fuel and also for fencing the } \\
\text { fields. Seeds are edible which are dried for making "Anar-dana" which is } \\
\text { used as condiment. }\end{array}$ \\
\hline 64 & $\begin{array}{l}\text { Pyrus pashia } \\
\text { Buch.-Ham. ex D. } \\
\text { Don./ej-161 }\end{array}$ & Batangi & Rosaceae & $\begin{array}{l}\text { The fruit is edible and is used against diarrhoea. The dried fruit may be } \\
\text { used after crushing. Fruit is edible and the leaves are also used as fodder. } \\
\text { Branches are used for fuel. }\end{array}$ \\
\hline 65 & $\begin{array}{l}\text { Quercus incana } \\
\text { Roxb./ej-162 }\end{array}$ & Rein, Shah-baloot & Fagaceae & $\begin{array}{l}\text { Pieces of bark are boiled in water to get their decoction, which is very } \\
\text { effective against joint pain and is also having cooling effect. Elongated } \\
\text { logs are used as guarders in roof thatching. Branches are used for fuel. }\end{array}$ \\
\hline 66 & $\begin{array}{l}\text { Ricinus } \\
\text { Communis } \\
\text { L./ej-167 }\end{array}$ & Arand, Hernoli & Euphorbiaceae & $\begin{array}{l}\text { The oil extracted from seeds of the plant is called "Castor oil" which is } \\
\text { used as purgative. The leaves are used as poultice in rheumatic joints. } \\
\text { Branches are used for fuel. }\end{array}$ \\
\hline 67 & $\begin{array}{l}\text { Rosa brunonii } \\
\text { Lindl./ej-168 }\end{array}$ & Jangli Gulab & Rosaceae & $\begin{array}{l}\text { Fresh flowers are externally massaged on skin infected from scabies. } \\
\text { Flowers petals are used to make "Gulkand" which is believed to be } \\
\text { effective against digestive and heart problems. The plant is used as } \\
\text { ornamental. }\end{array}$ \\
\hline 68 & $\begin{array}{l}\text { Rubus ellipticus } \\
\text { Smith./ej-169 }\end{array}$ & Aakha & Rosaceae & $\begin{array}{l}\text { Fruit is edible and is having cooling effect. Spiny branches are used as } \\
\text { fence around fields. Leaves are browsed by goats. }\end{array}$ \\
\hline
\end{tabular}


Table 1 Ethnobotanical uses of plants of Patriata, New Murree (Continued)

\begin{tabular}{|c|c|c|c|c|}
\hline 69 & $\begin{array}{l}\text { Rubus fruiticosus } \\
\text { L./ej-170 }\end{array}$ & Aakha & Rosaceae & $\begin{array}{l}\text { Fruits are edible and have cooling effect. Spiny branches are used in } \\
\text { fencing. Leaves are browsed by goats. }\end{array}$ \\
\hline 70 & $\begin{array}{l}\text { Rumex dentatis } \\
\text { L./ej-172 }\end{array}$ & Khoe, Jangli Palak & Polygonaceae & $\begin{array}{l}\text { The extract of the leaves is used as antiseptic against wounds and skin } \\
\text { problems. Young leaves are used as vegetable. The whole plant is used } \\
\text { for fodder. }\end{array}$ \\
\hline 71 & $\begin{array}{l}\text { Rumex haustatus } \\
\text { D. Don/ej-173 }\end{array}$ & Khatimmer & Polygonaceae & $\begin{array}{l}\text { Leaves are grinded and used against jaundice. Decoction of roots is also } \\
\text { used against jaundice. }\end{array}$ \\
\hline 72 & $\begin{array}{l}\text { Rumex nepelansis } \\
\text { Spreng./ej-174 }\end{array}$ & Khoe, Jangli Palak & Polygonaceae & $\begin{array}{l}\text { The extract of the leaves is used as antiseptic against wounds and skin } \\
\text { problems. Young leaves are used as vegetable. }\end{array}$ \\
\hline 73 & $\begin{array}{l}\text { Salix babylonica } \\
\text { L./ej-176 }\end{array}$ & Beiss & Salicaceae & $\begin{array}{l}\text { Grinded roots are used for their cooling effects. The wood of the plant is } \\
\text { used in making furniture. Dried branches are used for fuel. It is also } \\
\text { planted in sliding areas. }\end{array}$ \\
\hline 74 & $\begin{array}{l}\text { Sapindus } \\
\text { mukorrossii } \\
\text { Gaertn./ej-178 }\end{array}$ & Retha & Sapindaceae & $\begin{array}{l}\text { The fruits are soaked in water and are used in washing hairs to make } \\
\text { them healthy and silky. Dried branches are used for fuel. }\end{array}$ \\
\hline 75 & $\begin{array}{l}\text { Saussuria } \\
\text { heteromala DC./ } \\
\text { ej-180 }\end{array}$ & Kali Zeeri & Asteraceae & $\begin{array}{l}\text { Seeds are grinded and used against skin diseases especially scabies, } \\
\text { pimples etc. The plant is used for fodder. }\end{array}$ \\
\hline 76 & $\begin{array}{l}\text { Solanum nigrum } \\
\text { L./ej-187 }\end{array}$ & Mako, Kach maach & Solanaceae & $\begin{array}{l}\text { Leaves and fruits are cooked and used against abdominal swellings and } \\
\text { stomach-ache. It is also used as spinach by cardiac patients. }\end{array}$ \\
\hline 77 & $\begin{array}{l}\text { Solanum } \\
\text { surratense Burm. } \\
\text { F./ej-189 }\end{array}$ & Mokrhi, Kandiari & Solanaceae & $\begin{array}{l}\text { The extract of leaves is applied on body swellings to get relief. Its seeds } \\
\text { are burnt in "Chehlum" and the smoke is inhaled to get relief from } \\
\text { toothach. Fruits and leaves are boiled and the decoction is mixed in water } \\
\text { and used for taking bath against skin diseases. }\end{array}$ \\
\hline 78 & $\begin{array}{l}\text { Solanum villosum } \\
\text { (L.) Moench/ } \\
\text { ej-186 }\end{array}$ & Kach-maach & Solanaceae & The leaves are cooked and used as spinach by cardiac patients. \\
\hline 79 & $\begin{array}{l}\text { Sonchus asper } \\
\text { (L.) Hill/ej-190 }\end{array}$ & Duddal & Solanaceae & $\begin{array}{l}\text { Decoction of leaves and roots is taken orally against fever. It is also used } \\
\text { against pimples, diabetes, scabies and other skin problems in the form of } \\
\text { spinach. The plant is also used as fodder. }\end{array}$ \\
\hline 80 & $\begin{array}{l}\text { Spermadictyon } \\
\text { suaviolens Roxb./ } \\
\text { ej-192 }\end{array}$ & Phisanni & Rubiaceae & The leaves are used as fodder, and especially browsed by goats. \\
\hline 81 & $\begin{array}{l}\text { Swertia chiraita } \\
\text { (Wall.) C.B. } \\
\text { Clarke/ej-194 }\end{array}$ & Charaita & Gentianaceae & $\begin{array}{l}\text { The leaves are grinded and the paste is dissolved in water along with } \\
\text { some brown sugar and is used against fever especially malaria. }\end{array}$ \\
\hline 82 & $\begin{array}{l}\text { Swertia cordata } \\
\text { Wall./ej-195 }\end{array}$ & Charaita & Gentianaceae & $\begin{array}{l}\text { The leaves paste along with some brown sugar is used against fever } \\
\text { especially malaria. }\end{array}$ \\
\hline 83 & $\begin{array}{l}\text { Syzygium cuminii } \\
\text { (L.) Skeels/ej-197 }\end{array}$ & Jaman & Myrtaceae & $\begin{array}{l}\text { Fruits are edible and are believed to be effective against cardiac problems. } \\
\text { The dried seeds are grinded and the powder is used against diabetes. The } \\
\text { leaves are used for fodder purpose. Wood is used for fuel. Due to light } \\
\text { weight wood is used to make furniture. }\end{array}$ \\
\hline 84 & $\begin{array}{l}\text { Tribulus terestris } \\
\text { L./ej-202 }\end{array}$ & Bhakrha & Zygophyllaceae & $\begin{array}{l}\text { The whole plant is dried, powdered and is use to ease menstrual flow, } \\
\text { relieve constipation and its high dose is used in abortion. }\end{array}$ \\
\hline 85 & $\begin{array}{l}\text { Trichodesma } \\
\text { indica (L.) R.Br./ } \\
\text { ej-203 }\end{array}$ & Hundusi, Gao-zaban & Boraginaceae & $\begin{array}{l}\text { The leaves paste is mixed with water and brown sugar and is given orally } \\
\text { against diarrhoea and dysentery. }\end{array}$ \\
\hline 86 & $\begin{array}{l}\text { Verbena } \\
\text { officinale L./ } \\
\text { ej-206 }\end{array}$ & Chooroon & Verbenaceae & Leaves paste is used against rheumatic and joint pain. \\
\hline 87 & $\begin{array}{l}\text { Viola canescense } \\
\text { Wall. ex Roxb./ } \\
\text { ej-210 }\end{array}$ & Banafsha & Violaceae & $\begin{array}{l}\text { The leaves past is mixed with brown sugar to be used against cough, } \\
\text { cold and other respiratory problems. }\end{array}$ \\
\hline 88 & $\begin{array}{l}\text { Vitex negundo } \\
\text { L./ej-211 }\end{array}$ & Marvan & Verbenaceae & $\begin{array}{l}\text { Decoction of leaves is used orally in very small amounts, and externally for } \\
\text { taking bath against skin diseases. Leaves and branches are placed in } \\
\text { stored wheat grains and other cereals to avoid insect pests. Dried } \\
\text { branches are also used for fuel. }\end{array}$ \\
\hline 89 & $\begin{array}{l}\text { Woodfordia } \\
\text { fruiticosa (L.) S. } \\
\text { Kurz./ej-213 }\end{array}$ & Dhaawi, Taavi & Vitaceae & $\begin{array}{l}\text { Flowers are dried and powdered. This powder is used locally by females } \\
\text { for abortion. These are also used in fewer amounts to ease menstrual } \\
\text { flow. Leaves are used as fodder and Branches as fuel. }\end{array}$ \\
\hline
\end{tabular}




\section{Table 1 Ethnobotanical uses of plants of Patriata, New Murree (Continued)}

\begin{tabular}{|c|c|c|c|c|}
\hline 90 & $\begin{array}{l}\text { Xylosma } \\
\text { longifolium } \\
\text { Clos./ej-215 }\end{array}$ & Batti & Flacourtiaceae & $\begin{array}{l}\text { Dried branches are used for fuel. Long and straight branches are used as } \\
\text { support for various purposes. }\end{array}$ \\
\hline 91 & $\begin{array}{l}\text { Zanthoxylum } \\
\text { alatum Roxb./ } \\
\text { ej-216 }\end{array}$ & Timber, Timmer & Rutaceae & $\begin{array}{l}\text { Young fruits are grinded with seeds of Punica granatum, leaves of Mentha } \\
\text { longifolia and green chillies to make "Chatni". Its fruits are highly } \\
\text { carminative and also used against stomach-ach and dyspepsia. Young } \\
\text { branches are used as "Miswak" just like toothbrush. Leaves are browsed by } \\
\text { goats. Spiny branches are use as fence around fields. Straight branches are } \\
\text { used as walking sticks. }\end{array}$ \\
\hline 92 & $\begin{array}{l}\text { Zizyphus } \\
\text { mauritiana } \\
\text { Lam./ej-217 }\end{array}$ & Bair, Beri & Rhamnaceae & $\begin{array}{l}\text { Fruits are edible and used as digestive stimulant. Leaves are browsed by } \\
\text { goats. The spiny branches are used as fencing the fields. }\end{array}$ \\
\hline 93 & $\begin{array}{l}\text { Zizyphus } \\
\text { oxyphylla } \\
\text { Edgew./ej-218 }\end{array}$ & Amnui & Rhamnaceae & $\begin{array}{l}\text { Roots are boiled in water to get decoction which is used against scabies, } \\
\text { pustules and diabetes. Grinded roots are also used against jaundice. Fruits } \\
\text { are edible and leaves are browsed by goats. Spiny branches are used in } \\
\text { fencing the fields. }\end{array}$ \\
\hline
\end{tabular}

Where dependent variable Logit $\left(\mathrm{L}_{\mathrm{i}}\right)$ is $\log$ of odd ratios and $\mathrm{Xi}$ is the vector of all explanatory variables used in the regression analysis i.e. Woody and Non-Woody (WDN) Plants (by taking 1 for Woody Plants and 0 for non-woody Plants), Perennial and Annual (PAN) plants (by taking 1 for Perennial Plants and 0 for Annual Plants), Aerial and Undergrounds (AUG) plant parts (by taking 1 for Aerial Plant parts and 0 for Underground Plant parts), use of plant as Fruit (by taking 1 if there is use of plant as fruit otherwise 0 ) and fodder (by taking 1 if there is use of plant as fodder otherwise 0) while $\mathrm{Li}$ is constructed for Medicinal Use (MU) of plant.

Dependent variable in logit model is logit rather than a mean so coefficients are in logit. $\beta i$ represents the change in the logit of the probability associated with a unit change in the respective predictor holding all other predictors constant [15]. These types of interpretations are unfamiliar so an appropriate way is to interpret the marginal effects in the logit model. We constructed Marginal Effects for our analysis. Hence, to interpret parameter estimates through marginal effect, the slope coefficients of the logit model were transformed to yield estimates of the marginal effects i.e. the change in the predicted probability associated with the change in the covariates [16,17].

\section{Results and discussion}

\section{Ethnobotanical importance}

A total of 93 plant species belonging to 80 genera and 56 families are reported in the present communication being used by the natives for multi-purpose. The detailed inventory is provided in Table 1, which includes botanical names, followed by local name, family and ethnobotanical uses.

The study showed that people of the area are much dependant on the native flora for acquiring their basic requirements such as fodder, medicines, fruits, vegetables, fuel, furniture, roof thatching, fencing, etc. One of the major reasons is that the whole area is rural in nature and most of the people are not very well off. Therefore, most of them keep livestock along with other source of income. The analysis of the ethnobotanical data shows that a large number of plant species are used for fodder/forage purpose (27.93 percent). The area is a rangeland blessed with high number of palatable species, so there is great potential for livestock farming.

Ethnobotanical use categories are shown in Figure 1, which shows that almost equal proportion of species were used for medicinal as well as fodder for their domesticated animals (27.93 percent each). It was followed by fuel (16.90 percent), others (11.38 percent), wild fruit (6.55 percent), vegetable (5.52 percent) and ethno-veterinary (3.79 percent). With reference to their medicinal use (Figure 2), leaves were commonly used parts for making indigenous recipes (36.61 percent), followed by fruits (24.11 percent). Availability status of the species was also analysed and recorded in Figure 3, which shows that 37.23 percent species are abundantly present in study area, 43.62 percent species are common, 13.83 percent species are rare and 5.32 percent species are endangered in the area and need their conservation.

Due to absence of fuel source "local population" is totally dependant upon fuel wood species for their survival. They are extensively cutting forests for their fuel wood requirements without any knowledge of their extinction, so a number of species are rapidly decreasing in the study area. One way to reduce this pressure on the natural vegetation is that, people may be provided with alternate fuel sources like natural gas.

During interviews with the local people, it was noted that the ethnobotanical knowledge is becoming restricted only to the elder people, Hakeems, and pensaries (local herb sellers). Young generation is totally ignorant of this wealth. Advancement in science and technology has changed social setup; therefore young generation is leaving traditions and culture. 


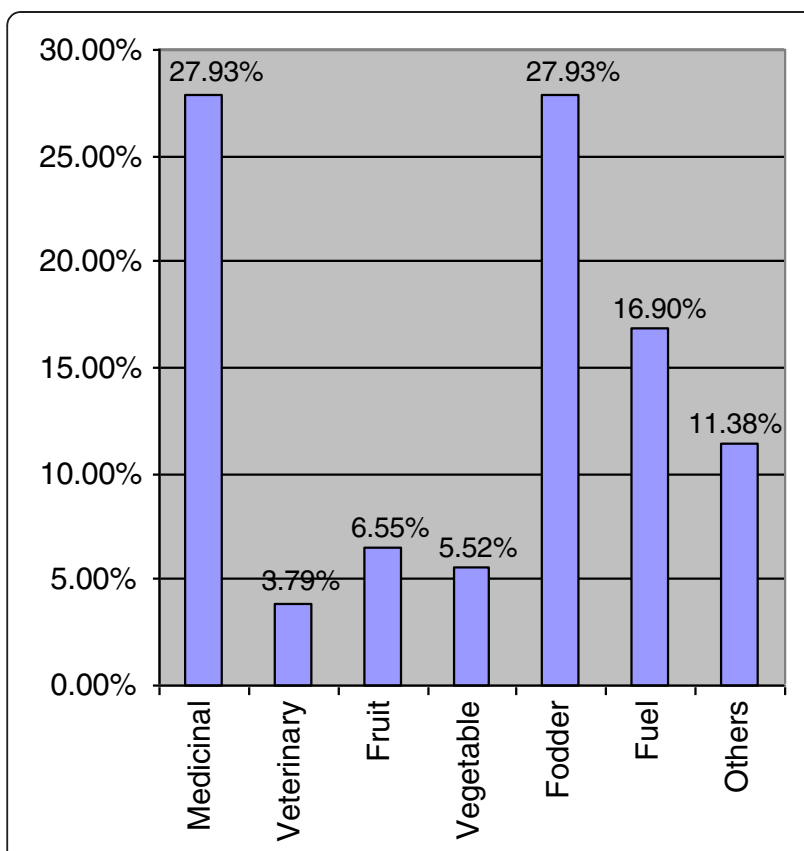

Figure 1 Ethnobotanical uses of flora of Patriata, New Murree.

\section{Some significant findings from logit expression}

The results reported in Table 2 reflect the logit estimates for medicinal use analysis for 93 plants. The table represents logit coefficients as well as odd ratios but a more comprehensive and meaningful interpretation was made through marginal effects (marginal probabilities). The effect of the variable WND shows that probability of woody plants to be used for medicinal purposes is 45.26 percentage point lower than that of non-woody plants.

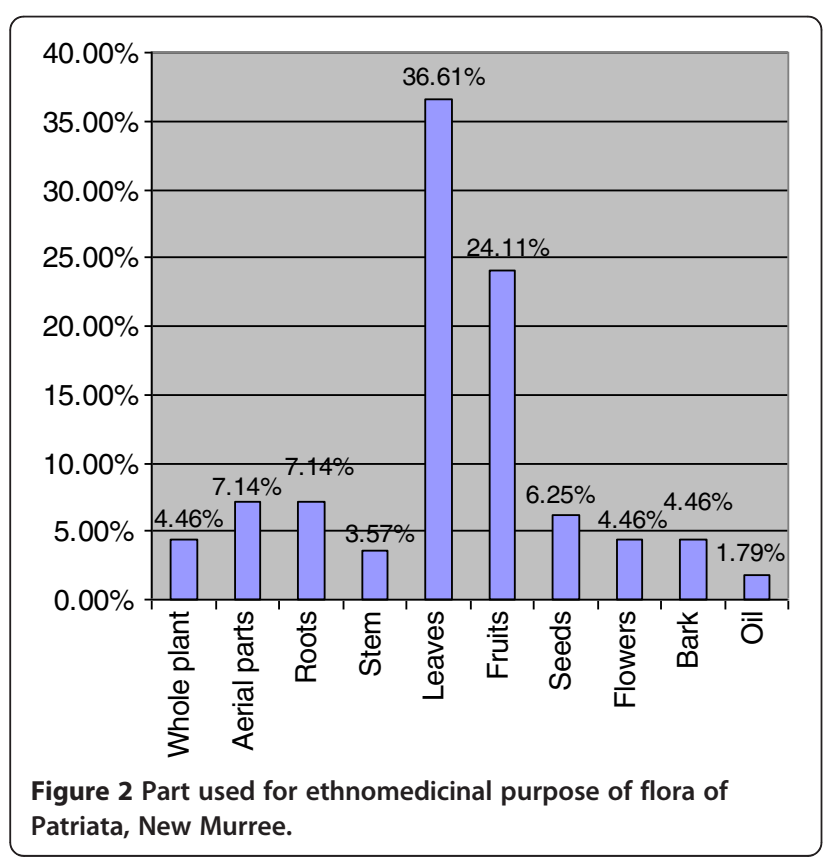

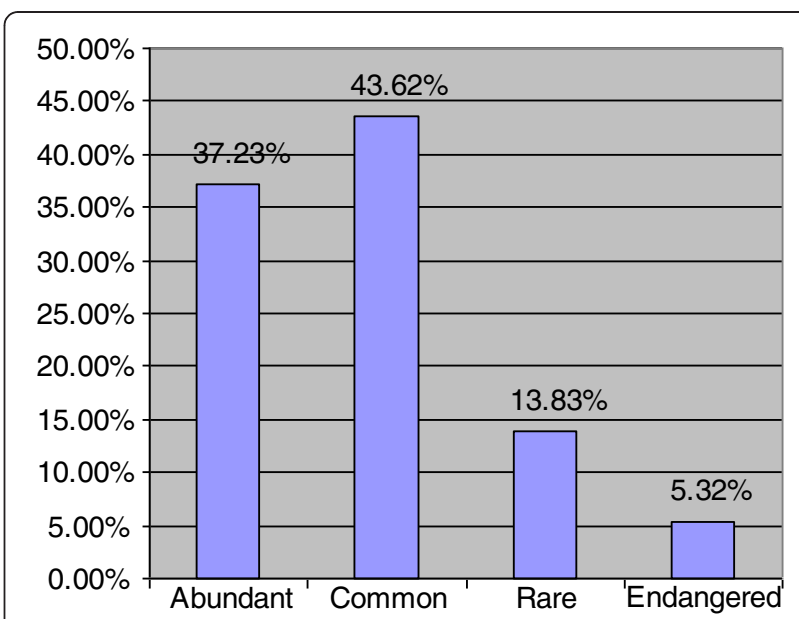

Figure 3 Availability of plants of Patriata, New Murree.

Thus, among the surveyed 93 species, non-woody plants have high tendency towards medicinal use of the plants as compared to woody plants (keeping the socio-economic characteristics of the communities in respective region constant). The probability of a perennial plant for medicinal use is about 95.18 percent higher than that of annual plants. So, there is likelihood of the fact that more the plant a perennial one, higher is the chance of its medicinal use in the specific region keeping all other probabilities constant. Annual plants are less likely to be directly associated with medicinal use of plants in that particular ecosystem. All such results are statistically significant.

On the other hand, probability of aerial plant parts in medicinal use is about 0.24 percent lower than underground plant parts. In other words, the aerial and underground plant parts of species of Patriata Ecosystem are almost equally eligible for the medicinal values. Similarly, the probability of fruits of plants for medicinal use is about 2 percentage point higher than non-fruit parts. The probability of fodder plants in medicinal use is 0.004

Table 2 Maximum likelihood estimates for medicinal use logit regression

\begin{tabular}{llllll}
\hline Covariate & Coefficient & Odd-Ratio & Z-Stat & P-Value & $\begin{array}{l}\text { Marginal } \\
\text { effects }\end{array}$ \\
\hline Constant & 21.04215 & - & 2.39 & 0.017 & - \\
\hline WND & -17.65597 & $2.15 e-08$ & -26.66 & 0.000 & -.452617 \\
\hline PAN & 16.67147 & $1.74 e+07$ & 5.06 & 0.000 & .9517718 \\
\hline AUG & -17.97821 & $3.96 e-08$ & -7.07 & 0.000 & -.0023579 \\
\hline FRUIT & 18.09735 & $7.24 e+07$ & 29.13 & 0.000 & .0199024 \\
\hline FODDER & -1.192138 & .3035714 & -0.15 & 0.881 & -.0004085 \\
\hline Pseudo R & & 0.1777 & & & \\
\hline Likelihood ratio test statistic & -29.407017 & & \\
\hline Wald Chi-Sq (5) & $848.02(0.000)$ & & \\
\hline Replications & 50 & & & \\
\hline
\end{tabular}


percentage point lower than non-fodder plants. This value is too low to be effective and also statistically insignificant showing that plants used as fodder are ineffective in medicinal use. All the variables are highly significant at less than 1 percent except fodder (which is statistically insignificant which might be due to the ignorance of the local community). The Wald Chi-Square test statistic is also very high with probability value less than 1 percent showing that model is highly significant. The overall significance of the model further authenticates the findings related to medicinal use of plants. All other empirical specifications including descriptive statistics have been shown in Additional file 1: Appendix-A.

One should be careful that the survey results are sensitive to the plant species and the vegetation under consideration in addition to socio-cultural characteristics of the dwellers of the region. But it can be specified that there exists either positive or negative association of medicinal use to the various characteristics of plant species. The probability of medicinal use of plants is fairly linked to the probability woody and non-woody, perennial and annual, aerial and underground characters of plants.

\section{Conclusion}

The present study reveals that ethnobotanical knowledge is found restricted to indigenous culture, so change in traditional culture will surely result in loss of this valuable treasure. There is need of hour to document this hidden treasure to avoid its extinction and the present study is a part of this effort. Based on the present investigation, there is need to authenticate medicinal and forest products of plants on scientific lines. On the other hands, conservation status should be determined of the native flora required for conserving endangered species. It has been determined that the probabilities of plant species for their medicinal use are associated to the woody or non-woody, aerial and underground, perennial and annual characters of plants. There is also an established association of medicinal use of plants to the fruits use. Non-woody plants have high tendency towards medicinal use of the plants as compared to woody plants. Annual plants are less likely to be directly associated with medicinal use of plants in the surveyed ecosystem. A further exploration in the same fashion in other ecosystems can lead us to some solid understanding of medicinal use of plants and its probabilistic association with other features of plant species and their respective taxonomies.

\section{Additional file}

Additional file 1: Appendix-A. Table A-1 Descriptive Statistics. Table A2 Coefficients in Logit Analysis. Table A-3 Odd Ratios in Logit Analysis. Table A-4 Marginal Effects in Logit Analysis.

\section{Competing interests}

The authors declare no competing interests.

\section{Authors' contributions}

MA designed the research project, provided comments and suggestions on the draft. EA conducted the field work, analysed the data and wrote the draft of manuscript. RQ conducted the field work and provided comments on the draft. GM and SKC conducted field work and analysed the data. AS and SS have conducted statistical analysis and analysed the manuscript. All authors have read and approved the final manuscript.

\section{Acknowledgments}

The authors are highly grateful to the local informants of Patriata, New Murree who fully cooperated and provided the important ethnobotanical data to them. Without their cooperation this research project would have never been completed.

\section{Author details}

${ }^{1}$ Department of Botany, PMAS-Arid Agriculture University Rawalpindi, Rawalpindi, Pakistan. ${ }^{2}$ Department of Economics, PMAS-Arid Agriculture University Rawalpindi, Rawalpindi, Pakistan.

Received: 13 September 2012 Accepted: 19 February 2013

Published: 27 February 2013

\section{References}

1. Balick MJ: Transforming ethnobotany for the new millennium. Ann Mo Bot Gard 1996, 83:58-66.

2. Ram J: Assessment of habitat diversity, forest vegetation and human dependence in the buffer zone of Nanda Devi Biosphere of Himalaya. Ph.D. Thesis. Nainital, India: Kamaun University; 2004.

3. Ghimire SK, McKey D, Ameeruddy-Thomas Y: Himalayan medicinal plant diversity in an ecologically complex high altitude anthropogenic landscape, Dolpo Nepal. Environ Conserv 2006, 33:128-140.

4. Lambert J, Srivastava J, Vietmeyer N: Medicinal Plants: Rescuing a Global Heritage Ed. USA: The World Bank; 1997.

5. Qureshi R, Bhatti GR: Ethnobotany of plants used by the Thari people of Nara Desert Pakistan. Fitoterapia 2008, 79:468-473.

6. Alam N, Shinwari ZK, Ilyas M, Ullah Z: Indigenous knowledge of medicinal plants of Chagharzai valley, District Buner, Pakistan. Pak J Bot 2011, 43(2):773-780.

7. Noor MJ, Kalsoom U: Ethnobotanical studies of selected plant species of Ratwal village, district Attock. Pakistan Pak J Bot 2011, 43(2):781-786.

8. Hazrat A, Nisar M, Shah J, Ahmad S: Ethnobotanical study of some elite plants belonging to Dir, Kohistan valley, Khyber Pukhtunkhwa, Pakistan. Pak J Bot 2011, 43(2):787-795.

9. Qureshi R: Medicinal flora of Hingol National Park, Baluchistan, Pakistan. Pak J Bot 2012, 44(2):725-732.

10. Rahim SMA: Working plan for the cantonment forest Murree (1997-98 to 200708). 108- Ravi Road Lahore: Development and working plan circle; 2000.

11. Nasir E, Ali Sl: Flora of Pakistan, (fasicles series 1-202). Pakistan: Dept. of Bot. University of Karachi; 1970-2003.

12. Ali SI, Qaiser M: Flora of Pakistan. Dept. of Bot. University of Karachi; 19932008.

13. Nasir YJ, Rafiq RA: In Wild Flowers of Pakistan. Edited by Roberts TJ. New York: Oxford Uni. Press; 1995:35-180.

14. Nasir E, Ali Sl: Flora of West Pakistan and Kashmir. Islamabad: Pakistan Agriculture Research Council; 1970-1995.

15. E Views 5 User's Guide: Quantitative Micro Software. USA: LLC; 2004.

16. Green WH: Econometric Analysis. 5th edition. Prentice Hall, Inc.; 2002.

17. Newell R, Soren A: Simplified marginal effects in discrete choice models. Discussion Paper 03-38. Washington: Resources for the Future; 2003.

doi:10.1186/1746-4269-9-13

Cite this article as: Ahmed et al:: Ethnobotanical appraisal and medicinal use of plants in Patriata, New Murree, evidence from Pakistan. Journal of Ethnobiology and Ethnomedicine 2013 9:13. 